\title{
Skala Penelitian Variabel Terprovokasi Dengan Melibatkan Responden Petugas Pengamanan Demonstrasi
}

\author{
Erik Saut Hatoguan Hutahaean ${ }^{1}$, Yuarini Wahyu Pertiwi ${ }^{1}$, Tiara Anggita Perdini ${ }^{2, *}$ \\ ${ }^{1}$ Fakultas Psikologi; Universitas Bhayangkara Jakarta Raya; Jl. Perjuangan 081, Marga \\ Mulya, Bekasi Utara; 02188955882/ +622188955871; e-mail: erik.saut@dsn.ubharajaya.ac.id, \\ yuarini.wp@dsn.ubharajaya.ac.id \\ 2 Fakultas Psikologi; Universitas Persada Indonesia YAI; JI. Pangeran Diponegoro \\ No.74, Kenari, Kec. Senen, Kota Jakarta Pusat, 0213926000; e-mail: \\ yuarini.wp@dsn.ubharajaya.ac.id, tiaraanggitaperdini@gmail.com
}

* Korespondensi: e-mail: tiaraanggitaperdini@gmail.com

Submitted: 05/01/2022; Revised: 14/01/2022; Accepted: 21/01/2022; Published: $31 / 01 / 2022$

\begin{abstract}
Police officers from the Mass Control Unit (DALMAS) are a police unit with the task of providing security against demonstrations. The chaotic conditions of the demonstration became a reality that they had to face while on duty. The rioting of the demonstrators not only poses a big risk, but in the rioting there are also efforts that can provoke DALMAS members to become emotional and aggressive, in other words provoked. The provoked variable is a very interesting study, but from the many results of research on aggressive behavior, a measurement scale that can be used to obtain quantitative data has not been found. This study tries to compile constructs and items to be able to measure the state of being provoked. The measurement construct was compiled and tested for conformity by involving 5 assessor panelists, and then 35 members of DALMAS were involved to conduct trials to determine the reliability of the items. The result managed to get a number of items that can be used to measure the state of being provoked, the measurement bits show a fairly accurate reliability. Although the existing items are able to measure variables, these results have not involved a large number of respondents.
\end{abstract}

Keywords: Instrument, Provoked Scale, Research

\begin{abstract}
Abstrak
Petugas polisi satuan Pengendali Masa (DALMAS) merupakan satuan kepolisian dengan tugas melakukan pengamanan terhadap aksi demonstrasi. Kondisi unjuk rasa yang rusuh menjadi kenyataan yang harus dihadapi mereka saat bertugas. Aksi rusuh dari demonstran tidak hanya memunculkan resiko besar, tetapi dalam aksi rusuh juga terjadi upaya-upaya yang dapat memancing anggota DALMAS menjadi emosional dan agresi, dengan kata lain terprovokasi. Variabel terprovokasi menjadi suatu kajian yang sangat menarik, namun dari sekian banyaknya hasil penelitian mengenai perilaku agresi belum ditemukan skala pengkuran yang dapat digunakan untuk mendapatkan data kuantitatif. Penelitian ini mencoba untuk menyusun konstruk dan butir untuk dapat mengukur keadaan terprovokasi. Konstruk pengkuran disusun dan diuji kesesuaiannya dengan melibatkan 5 orang panelis penilai, dan selanjutnya sebanyak 35 anggota DALMAS dilibatkan untuk melakukan uji coba untuk mengetahui keterhandalan butir. Hasilnya berhasil mendapatkan sejumlah butir yang dapat digunakan untuk mengukur keadaan terprovokasi, bitur pengkuran memperlihatkan kehandalan yang cukup akurat. Meskipun butir-butir yang ada sudah mampu mengukur variabel, namun hasil ini belum melibatkan responden dalam jumlah yang besar.
\end{abstract}

Kata kunci: Instrumen, Skala Terprovokasi, Penelitian 


\section{Pendahuluan}

Provokasi adalah salah satu bentuk dari komunikasi masa, dilakukan oleh sekumpulan demonstran atau individu dengan tujuan menimbulkan reaksi marah pada targetnya (Mauss, Cook \& Gross, 2007b). Tujuan provokasi untuk membuat orang lain marah, itulah yang menjadi penyebab bahwa penjelasan mengenai provokasi diarahkan kepada reaksi balasan kemarahan (Bushman, 2002). Pedersen, Denson, Goss, Vasquez, Kelley \& Miller (2011) menyatakan bahwa provokasi kemarahan adalah kemarahan yang dipilih sebagai konteks emosional karena terjadi terprovokasi, atau karena berfikir tentang insiden yang memprovokasi. Provokasi juga dijelaskan sebagai suatu hasrat emosi negatif yang intensif, dilakukan dengan cara menyampaikan penghinaan, dan bahkan serangan yang dapat menyebabkan cidera (Scott, Stepp \& Pilkonis, 2014).

Ketika terjadi pada orang-orang yang tidak bisa mengendalikan diri, provokasi mengakibatkan menipisnya kontrol diri dan ego, sehingga lebih mudah untuk menampilkan respon marah (Wang, She, Colarelli, Fang, Meng, Chen, Zhang \& Zhu, 2018). Respon balasan marah akan menjadi lebih mungkin dilakukan terhadap orang-orang yang memberikan sindiran dibandingkan dengan yang memberikan pernyataan netral (Aronson, Wilson, Akert \& Sommers, 2016), respon dilakukan tidak hanya sebagai reaksi balasan, tetapi juga bersamaan dengan kewenangan menjaga ketertiban dan keamanan. Dalam artikelnya yang mengulasi mengenai agresi pada manusia, Anderson \& Bushman (2002) menguraikan konsep tentang provokasi yang berdampak kepada munculnya agresi, dapat terjadi melalui proses interaksi sosial.

Saat seseorang berhadapan dengan aksi demonstrasi, penempatan provokasi ('provocation plot') dapat dijelaskan melalui tiga cara, Ketiga penempatan tersebut menerangkan bahwa provokasi menyajikan tentang kekerasan sebagai pembalasan, kekerasan sebagai pertahanan, dan kekerasan oportunistik (Wahlström, 2011). Dalam kondisi demontrasi yang rusuh, polisi dapat terpancing memberikan reaksi balasan terhadap pengunjuk rasa yang rusuhTerdapat beberapa repon yang biasanya ditampilkan seseorang saat terprovokasi (Wang et al., 2018). Salah satunya adalah Sulit mengendalikan diri, sehingga tidak mudah untuk menghindar dari respon agresif (Sutatminingsih \& Tuapattinaja, 2019).

Studi dari Long, Felton, Lilienfeld \& Lejuez (2014) berhasil mengungkap bahwa sebelum berada pada kondisi emosi terpancing, diketahui bahwa untuk membalas provokasi akan membuat pertimbangan tertentu Hasil studi lainnya juga berhasil mengungkap pada sisi lainnya. Apabila seseorang gagal menahan pancingan, maka dalam keadaan terpovokasi mengakibatkan muncul reaksi marah sebagai upaya untuk membalas ditampilkan (Miles, Menefee, Wanner, Teten \& Kent, 2015). Kajian teori yang diuraikan oleh Wahlström (2011) menerangkan bahwa reaksi seperti marah karena terpancing dapat terjadi saat demonsrtasi, karena orang yang terpancing dalam keadaan terprovokasi. Studi terdahulu mengenai keadan terporovokasi sudah jelas menggambarkan tentang batasan-batasan nyata tentang kondisi terprovokasi. Namun belum menguraikan mengenai butir pengukuran yang dapat digunakan untuk mendapatkan data kuantitatif dari varibel terprovokasi. Belum tersedianya instrument alat 
ukur penelitian mungkin sangat dapat menghambat proses penelitian tentang terprovokasi dalam memperoleh data nomotatik. Sejalan dengan penelitian kami sebelumnya, penelitian kali ini akan meneruskan pembahasan mengenai provokasi (Hutahaean, Pertiwi, Dayita Pohan, Perdini, \& Bastoro, 2021). Oleh sebab itulah penelitian ini memiliki tujuan untuk menkonstruk instrument skala penelitian keadaan terprovokasi.

\section{Metode Penelitian}

Penelitian ini mencoba menyusun konstruk dan butir pengukuran untuk variabel terprovokasi. Konstruk disusun dengan melibatkan teori yang mendeskripsikan keadaan saat seseorang terprovokasi, yang terlihat dengan indikator : sulit mengendalikan diri, berkurangnya kekuatan untuk mengendalikan diri, kontrol diri menipis, mengalami ego deplesi dan bergesernya motivasi (Wang, She, Colarelli, Fang, Chen, Zhang \& Zhu, 2018). Lima indikator tersebut kemudian dikembangkan untuk disusun menjadi pernyataan pengukuran, untuk kemudian diuji taraf relevansinya.

Tabel 1. Pernyataan Untuk Pengukuran Keadaan Terprovokasi

\begin{tabular}{|c|c|c|c|}
\hline No. & Butir Item & No & Butir Item \\
\hline 1. & $\begin{array}{l}\text { Saat melihat demonstran melempar batu } \\
\text { kepada saya, sulit rasanya bagi saya untuk } \\
\text { tidak membalas orang tersebut }\end{array}$ & 6. & $\begin{array}{l}\text { Usaha saya dalam menahan diri tidak akan } \\
\text { berkurang sedikitpun, walau ada banyak } \\
\text { orang menyerang barisan anggota polisi } \\
\text { yang mengamankan demonstrasi }\end{array}$ \\
\hline 2. & $\begin{array}{l}\text { Mudah bagi saya untuk menahan diri agar } \\
\text { tidak membalas orang lain, meskipun orang } \\
\text { tersebut bertubi-tubi melakukan serangan } \\
\text { terhadap saya dan rekan lainnya }\end{array}$ & 7. & $\begin{array}{l}\text { Pengerusakan water canon oleh } \\
\text { demonstran dapat membuat saya kesulitan } \\
\text { untuk mencegah hasrat-hasrat dari dalam } \\
\text { diri melakukan perilaku negative terhadap } \\
\text { demonstran }\end{array}$ \\
\hline 3. & $\begin{array}{l}\text { Lemparan molotov yang diarahkan kepada } \\
\text { saya secara langsung membuat kendali diri } \\
\text { yang ada pada saya melemah }\end{array}$ & 8. & $\begin{array}{l}\text { Saya dapat menahan setiap hasrat buruk } \\
\text { untuk membalas demonstran, meskipun } \\
\text { mereka melempari batu kepada kendaraan } \\
\text { dinas dimana saya berada didalamnya }\end{array}$ \\
\hline 4. & $\begin{array}{l}\text { Kontrol diri yang saya miliki tidak akan } \\
\text { melemah, meskipun saya melihat banyak } \\
\text { orang yang merusak aset-aset milik } \\
\text { kepolisian }\end{array}$ & 9. & $\begin{array}{l}\text { Dorongan untuk mengendalikan diri yang } \\
\text { ada pada saya cenderung semakin } \\
\text { menurun, ketika ada pihak-pihak yang } \\
\text { secara terus menerus melempari batu } \\
\text { kepada saya dan rekan lainnya }\end{array}$ \\
\hline 5. & $\begin{array}{l}\text { Kontrol diri yang ada pada saya menjadi } \\
\text { lemah, jika melihat ada banyak orang yang } \\
\text { merusak kendaraan dinas polisi }\end{array}$ & 10. & $\begin{array}{l}\text { Usaha dari dalam diri saya tidak akan jadi } \\
\text { menurun, meskipun ada pihak-pihak yang } \\
\text { mendorong-dorong barisan polisi yang } \\
\text { saya berada didalam barisan tersebut }\end{array}$ \\
\hline
\end{tabular}

Sumber: Hasil Pengolahan Data (2022)

Teknik uji relevansi butir dengan teori dilakukan dengan melibatkan 5 orang panelis yang berperan untuk menilai kesesuaian butir pengukuran dengan konsep teorinya. Dengan kata lain uji validitas isi terhadap konstruksi butir pengukuran dan teorimya diuji dengan proses penilaian Subject Matter Experts (SMEs). Ahli yang dimaksid berperan memberikan penilaian untuk mendapatkan kesesuaian antara butir pengkuran dengan domain dan tujuan pengukuran (Crotts, Sireci, \& Zenisky, 2012). Lima ahli yang dilibatkan memiliki latar belakang praktisi dan keilmuan yang terkait dengan kajian tentang kepolisian dan psikologi kepolisian, Nilai yang didapatkan dari pandangan ahli menjadi dasar untuk menyusun butir skala penelitian dan kemudian melanjutkannya dengan proses uji coba empiris terhadap butir penukuran. Teknik 
hitung yang digunakan adalah dengan menggunakan koefisien alpha, berdasarkan satu kali penyajian alat ukur (single trial administration). Selanjutnya nilai koefisien alpha menjadi dasar untuk mengetahui eror pengukuran. Tahapan yang terakhir dalam proses mengontruksi alat ukur terprovokasi adalah dengan melakukan uji exploratory factor analysis (EFA). Bagian ini dilakukan untuk mereduksi variabel pengkuran yang asli menjadi variabel pengkuran. Sehingga akan menghasilkan adanya faktor atau dimensi yang baru dengan jumlah yang lebih minimal dibandingkan dengan dimensi yang sudah ada sebelumnya,

\section{Hasil dan Pembahasan}

Butir penelitian yang telah disusun berdasarkan 5 dimensi, diuji relevansinya dengan meminta penilaian dari loma penlis. Proses menilainya adalah dengan didasarkan kepada kapasitas kelimuannya, dalam hal ini panelis memiliki latar belakang pada bidang kelimuan yaitu psikologi, kepolisian dan hukum. Hasil penilaian dari panelis memperlihatkan nilai $\mathrm{V}$ lebih besar dari 0.97 (batas minimal untuk 5 panelis). Hasil ini ditemukan pada seluruh butir dan juga pada semua skala pengukuran. Sehingga dengan demikian butir pengukuran yang disusun adalah relevan dengan tujuan pengukuran dan sesuai dengan teori yang digunakan.

Tabel 2. Hasil Penilaian CVR Skala Terprovokasi

\begin{tabular}{|c|c|c|c|c|c|c|c|c|c|c|}
\hline \multirow{2}{*}{ Panelis } & \multicolumn{10}{|c|}{ Butir Item } \\
\hline & 1 & 2 & 3 & 4 & 5 & 6 & 7 & 8 & 9 & 10 \\
\hline$A$ & 3 & 3 & 3 & 2 & 4 & 4 & 4 & 3 & 4 & 4 \\
\hline B & 3 & 3 & 4 & 4 & 4 & 3 & 3 & 4 & 3 & 3 \\
\hline $\mathrm{C}$ & 4 & 3 & 3 & 3 & 3 & 2 & 3 & 4 & 3 & 3 \\
\hline $\mathrm{D}$ & 3 & 3 & 3 & 3 & 3 & 3 & 4 & 3 & 3 & 4 \\
\hline$E$ & 3 & 3 & 3 & 3 & 3 & 3 & 3 & 3 & 3 & 3 \\
\hline Total & 16 & 15 & 16 & 15 & 17 & 15 & 17 & 17 & 16 & 17 \\
\hline Koefisien & 1.067 & 1 & 1.067 & 1 & 1.133 & 1 & 1.13 & 1.133 & 1.067 & 1.133 \\
\hline
\end{tabular}

Hasil hitung penilaian dari panelis memperlihatkan nilai koefsien $\geq 1$ (lebih besar dari atau sama dengan satu), dan batas nilai koefisien untuk lima panelis adalah sebesar 0.97. Seperti terlihat pada data pada tabel di atas, bahwa seluruh butir pengukuran memiliki total skor pada setiap butir berada pada rentangan 15 hingga 17, dan saat dihitung nilai koefisiennya berhasil mendapatkan bahwa sepuluh butir yang telah disusun dinilai relevan, dimana butir yang disusun dianggap relevan dengan teorinya dan relevan dengan maksud pengukurannya. Sampai pada analisis hitung penilaian dari panelis, butir pengkuran yang disusun dari lima diemensinya sudah cukup relevan. Selanjutnya sepuluh butir yang ada diujicobakan untuk melihat tingkat keterhandalannya berdasarkan konsep daya diskriminasi butir penelitian.

Alat ukur skala terporovokasi yang diujicobakan terdapat sebanyak 10 butir pernyataan. Berdasarkan hasil hitung daya beda aitem mendapatkan terdapat 1 butir yang dianggap kurang optimal pada butir pengukuran no 1 , karena nilai alpha jika butir dihapus adalah sebesar 0.888 sedangkan nilai alpha statistiknya (point estimate) adalah sebesar 0.884 . Sehingga hasil hitung tersebut mencerminkan bahwa nilai alpha jika butir dihapus adalah p>point estimatenya, meskipun koefisien korelasinya $0,462(p>0.300)$. Hasil ini mengindikasikan terdapat sebanyak 
$11 \%$ eror pengukuran, konsekuensinya aka nada satu butir yang dianggap tidak layak digunakan

Tabel 3. Sebaran Nilai Alpha Apabila Butir di Diskriminasikan Skala Terprovokasi

\begin{tabular}{|c|c|c|}
\hline \multirow[b]{2}{*}{ Item } & \multicolumn{2}{|c|}{ Jika Butir Terdrop } \\
\hline & McDonald's $\omega$ & Cronbach's $\alpha$ \\
\hline 1. & 0,870 & $0,888^{*}$ \\
\hline 2. & 0,853 & 0,877 \\
\hline 3. & 0,866 & 0,867 \\
\hline 4. & 0,852 & 0,872 \\
\hline 5. & 0,845 & 0,871 \\
\hline 6. & 0,854 & 0,872 \\
\hline 7. & 0,863 & 0,879 \\
\hline 8. & 0,834 & 0,860 \\
\hline 9. & 0,849 & 0,871 \\
\hline 10. & 0,866 & 0,866 \\
\hline
\end{tabular}

Merujuk kepada nilai statistic alpha diperoleh hasil hitung bahwa butir pertama nilai alpha lebih besar dari nilai alpha statistiknaya yaitu sebesar 0.884. Sehingga hasilnya mendapatkan bahwa $0.888>0.884$, artinya jika butir pertama dihapus akan mengakibatkan nilai alpha meningkat, dengan kata lain maka butir pertama merupakan aitem yang tidak dapat digunakan karena mengakibatkan terjadinya menurunnya keterhandalan maksud pengukuran. Maka dengan demikian Sembilan butir lainnya berhasil memperlihatkan kehandalannya dalam mengukur keadaan saat seseorang terprovokasi.

Hasil hitung uji Kaiser Mayer-Olkin mendapatkan nilai keseluruhan MSA sebesar 0.696 dan tidak ditemukan ada butir yang hasil hitungnya $\leq 0.500$. Berdasarkan tabel di bawah terlihat bahwa hasil hitung pada butir 1 sampai 10 memiliki nilai MSA lebih besar dari skor-skor MSA yang ada di dalamnya. Data ini dapat diartikan bahwa butir-butir pengukuran dapat diuji dengan menggunakan EFA, angka MSA yang ada menandakan bahwa proses analisis faktor dapat dilakukan (appropriateness of factor anlysis).

Tabel 4. Kaiser-Meyer-Olkin Test

\begin{tabular}{cc}
\hline & MSA \\
\hline Overall MSA & 0,696 \\
\hline V1. F & 0,722 \\
\hline V2. UF & 0,850 \\
\hline V3. F & 0,822 \\
\hline V4. UF & 0,679 \\
\hline V5. F & 0,596 \\
\hline V6. UF & 0,548 \\
\hline V7. F & 0,690 \\
\hline V8. UF & 0,766 \\
\hline V9. F & 0,555 \\
\hline V10. UF & 0,817
\end{tabular}

Sumber: Hasil Pengolahan Data (2022)

Hasil hitung MSA berhasil didapatkan dan selanjutnya menjadi rujukan untuk melakukan eksplorasi dimensi atau faktor mana saja yang akan dipertahankan untuk selanjutnya dipertahankan dalam proses analisis; Berdasarkan konstruk teori yang ada, variabel terprovokasi memiliki 5 dimensi dan kemudian dikembangkan dalam proses penelitian ini 
menjadi 10 butir pengukuran. Selanjutnya analisis hitungan diarahkan untuk mengetahui besaran persentase suatu faktor dalam menjelaskan varians dari keseluruan butir yang ada.

Tabel 5. Factor Characteristics

\begin{tabular}{lccc} 
& SumSq. Loadings & Proportion var. & Cumulative \\
\hline F1 Sulit kendalikan diri & 1.993 & 0.199 & 0.199 \\
\hline F2 Kurang kekuatan kendalikan diri & 1.830 & 0.183 & 0.382 \\
\hline F3 Kontrol diri menipis & 1.596 & 0.160 & 0.542 \\
\hline F4 Mengalami depresi ego & 1.486 & 0.149 & 0.690 \\
\hline F5 Motivasi bergeser & 1.134 & 0.113 & 0.804 \\
\hline
\end{tabular}

Sumber: Hasil Pengolahan Data (2022)

Hasil uji karakteristik dimensi dari variabel keadaan terporovokasi memperlihatkan keseluruhan faktor yang ada dapat menjelaskan $80.4 \%$ variansi pengukuran yang dilihat dari 5 faktor/dimensi. Hasil hitung ini menandakan bahwa varians pengukuran berasal dari 8.04 butir pengkuran. Lebih detil lagi diketahui bahwa dimensi pertama menyumbangkan 19.9\% dalam menjelaskan variansi pengkuran yang dilakukan melalui 10 butir penelitian. Hasil hitung karakteristik faktor memperlihatkan besaran kemampuan faktor menjelaskan variansinya. Faktor 1 (dimensi kendalikan diri) memberikan sumbangan sebanyak 19.9\% dalam menjelaskan variansi pengkuran. Faktor 2 menyumbang sebanyak $18.3 \%$ dalam menjelaskan variansi pengkuran, Faktor 3 memberikan sumbangan sebanyak $16 \%$ dalam menjelaskan terjadinya variansi pengkuran, faktor 4 memberikan sumbangan sebanyak $14.9 \%$ dalam menjelaskan variansi pengkuran, dan yang terakhir faktor 5 memberikan kontribusi sebesar $11.3 \%$ dalam menjelaskan variansi pengukuran.

Merujuk kepada hasil hitung karakteristik faktor pada gambar 1 berhasil diketahui bahwa masing-masing dimensi memiliki besaran yang unik dalam menjelaskan varians pengkuran. Kesulitan mengendalikan diri saat terprovokasi varians pengkurannya adalah berasal dari 1.5944 butir, Kurangnya kekuatan untuk mengendalikan diri saat terprovokasi hasil hitungnya mendapatkan bahwa varians pengkurannya berasa dari 1,464 aitem. Kontrol diri menipis saat terporovokasi mendapatkan fakta bahwa varians pengkurannya berasal dari 1.2768 butir pengukurn.. Hasil hituang terhadap dimensi deplesi ego ketika terprovokasi mendapatkan fakta bahwa variansi pengukuran berasal dari 1.1888 pengukuran. Dimensi motivasi bergeser saat terporovokasi menyumbangkan varians yang paling sedikit, yaitu berasal dari 0.9072 butir aitem. Hasil hitung varians pengkuran memberikan fakta hasil hitung bahwa 10 butir aitem yang dieksplorasi melalui 5 dimensinya (faktor) kurang lebihnya hanya ada 8 butir aitem yang dianggap dapat menjelaskan variansi pengkuran. Merujuk kepada gambar diagram loading faktor dapat terlihat bahwa dua butir aitem yang kurang dapat menjelaska variansi pengkuran keadaan terprovokasi adalah butir aitem 1 dan butir aitem 9 . 


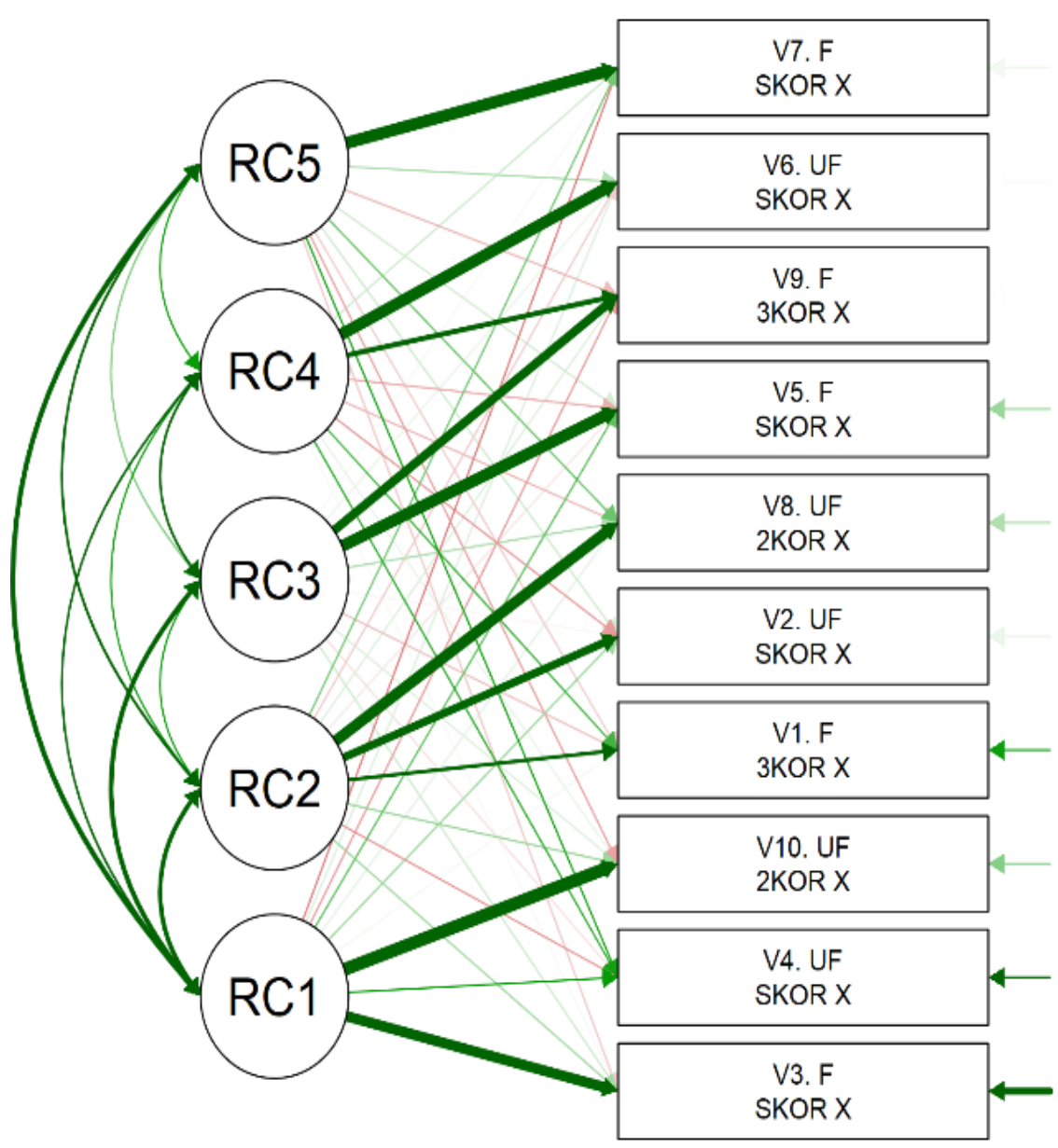

Sumber: Hasil Pengolahan Data (2022)

Gambar 1. Hasil Hitung Karakteristik Faktor

\subsection{Pembahasan}

Validitas adalah suatu konsep yang digunakan untuk mengukur kemampuan instrument relevan dengan konstruknya, instrument mewakili konstruk dan target pengukuran (Anastasia 1998). Terdapat tiga aspek penting yang menjadi tolak ukuranya. Tiga aspek yang dimaksud adalah definisi domain (operasionalnya), representasi domain (keseseuaian konten dengan pengukuran dengan domain pengkuran, dan relevansi domain (Sireci, 1998). Merujuk kepada teori pendahulu Aiken (1980). menjelaskan bahwa konsep CVR (content validity ratio) adalah menghitung koefisien validitas isi yang didasarkan pada penilaian dari panel ahli terhadap butir pengukuran, dimana nilai yang diberikan panelis dianggap merepresentasikan sejauh mana item mewakili konstrak yang diukur.

Mengukur keadaan terporovokasi memerlukan adanya suatu keadaan yang dapat memancing kemarahan, perlu melalui pengalaman yang nyata pribadi dan dikolaborasikan dengan teorinya. Studi yang diterangkan oleh Dewall, Anderson, \& Bushman (2011) mengruaikan bahwa munculnya agresi yang disebabkan karena ada provokasi, dimana pada orang-orang yang terprovokasi menjadi terhasut sehingga memberikan agresi balasan. Rangsangan lingkungan dapat membuat terbentuknya episode keadaan yang mengganggu 
stabilitas emosi, terlihat melalui kegigihan dalam berjuang menjaga emosi positif ataupun terjatuh ke dalam emosi negatif (Thompson, 2011; Branch, 2015).

Provokasi dapat menghasilkan respon agresi, disebabkan karena provokasi dan retaliasi (aksi balasan) berjalan secara simultan (Juujärvi, Kaartinen, Laitinen, Vanninen \& Pulkkinen, 2006).Butir pengukuran yang disajikan kepada panelis mendapatkan hasil bahwa keseluruhan butir dianggap relevan (sesuai dengan batas minimal nilai koefisiennya). Menurut Crotts et al (2012) terpenuhinya batas minimal koefisien validitas isi merepresentasikan bahwa butir pengkuran dinilai sudah sudah sesuai dengan tujuan pengkurannya. Maka dengan demikian butir pengkuran dianggap sudah sejalan dengan tujuan pengkuran. Dalam hal ini dianggap sudah relevaan untuk dapat mengkur kondisi terprovokasi melalui lima dimensi terprovokasi (Wang, She, Colarelli, Fang, Chen, Zhang \& Zhu, 2018).

Koefisien alpha memiliki makna bahwa dalam melakukan pengkuran masih ada ditemukan hal-hal yang membuat terjadinya eror pengkuran (Anastasia 1998). Apabila suatu alat ukur memiliki nilai statistik alpha 0.884, maka itu menunjukan dari 10 butir aitem diketahui terdapat eror pengukuran sebanyak 12\%. Artinya ditemukan ada sebanyak 1.2 butir dianggap mengakibatkan terjadinya eror pengkuran. Terlihat butir pengkuran no 1 tidak konsisten dalam mengukur keadaan terprovokasi dibandingkan dengan butir-butir yang lainnya. Apabila merujuk kepada penjelasan mengenai provasi yang berasa dari Wang, She, Colarelli, Fang, Chen, Zhang \& Zhu (2018), maka dari itu hasil hitung berhasil mengetahui bahwa eror pengkuran terjadi pada butir no 1 yang disusun berdasarkan dimensi ketidak sanggupan untuk mengendalikan diri Akan tetapi temuan ini perlu dilanjutkan kepada analisis varians pengkuruan.

Reio \& Shuck (2015) memberikan penjelasan bahwa EFA dapat menyempurkanakan dan mengembangkan instrument yang baru, dan mengkesplorasi katerkaitan hal-hal yang dapat diobservasi untuk kemudian digunakan menguatkan konsep teori dan hingga membangun teori. Hasil hiutng variansi pengkuran memberikan fakta bahwa terdapat dua butir yang lemah variansi pengkurannya. Sehingga perlu dilakukan pemeriksaan terhadap karakteristik butirnya, berupa pemeriksaan karakteristik provokasi yang terkandung di dalam butirnya. Ternyata ada dua butir pengkuran yang karakteristiknya sama, yaitu butir 1 dan 9 , keduanya mengandung muatan provokasi subjek dilempari batu. Seperti penjelasan dari Thompson (2011) bahwa untuk mengetahui kondisi terprovokasi haruslah memperhatikan rangsangan lingkungan yang dapat menimbulkan gangguan stabilitas emosi, dan rangsangan yang dapat mengakibatkan menurunnya kegigihan dalam menjaga emosi positif. Maka dengan demikian dalam pengkuruan provokasi yang berupa lemaparan batu terhadap subjek (petugas yang mengamankan) cenderung lemah pengaruhnya dalam membentuk keadaan terprovokasi. Ketika mengamankan aksi demonstrasi yang rusuh seluruh anggota pada dasarnya sudah dilengkapi dengan pengaman diri yang dapat melindungi dirinya dari serangan demonstran, namun tidak ada konsep perlindungan untuk menjaga asset kendaraan dinas dari serangan demonsrtan yang rusuh, dan ternyata lemparan batu terhadap kendaraan dinas menjadi suatu 
kondisi yang dapat menjelaskan varians pengkuran keadaan terprovokasi (Junaidi \& Marzuki, 2016).

Sebagaimana hasil hitung variansi pengkuran diketahui bahwa hanya terdapat $80.4 \%$ variansi. Apabila merujuk kepada hasil hitung tersebut, maka seharusnya terdapat lebih dari 1 butir pengukuran, karena ada $20 \%$ butir yang tidak dapat kategorikan sebagai varians pengkuran. Berarti kurang lebihnya terdapat 2 butir aitem yang tidak termasuk varians pengkuran, yaitu untuk butir aitem nomer 1 dan butir aitem nomer 9. Merujuk kepada pernyataan butir aitem, dari 10 butir yang ada terdapat 3 butir yang berisi provokasi dilempari batu oleh demonstran, yaitu butir nomer 1, 8, dan 9. Mendalami ketiga butir tersebut ternyata pernyataan butir pada nomer 1 dan 9 situasi demonstran melempar batu tidak dapat menyumbangkan variansi pengkuran keadaan terprovokasi, hal ini terjadi karena pada kedua butir menunjukan bahwa lemparan batu ditujukan kepada subjeknya. Berbeda dengan butir nomer 8, lemparan batu dilakukan terhadap asset milik kendaraan instansi Kepolisian, sebagai catatan bahwa penting diingat bahwa responden penelitian adalah anggota yang pernah bertugas melakukan pengamanan demonstrasi.

\section{Kesimpulan}

Mengukur keadaan terporovokasi pada anggota polisi DALMAS dapat dilakukan dengan menggunakan konsep teori terprovokasi, Konseptual teori dengan lima dimensi yang dipelajari dalam penelitian, berhasil mendapatkan fakta empiris yang dapat mendukung penguatan penyusunan alat pengumpul data untuk variabel keadaan terprovokasi. Konsep teori yang dimaksud adalah bahwa keadaan terporovokasi tidak hanya menggambarkan ketidakmampuan menahan dirim tetapi juga di dalam pengkurannya perlu juga ada situasisituasi yang karakteristiknya terkandung perilaku provokatif menyerang dari demonstran. Salah satu bentuk perilaku provokatif (dimunculkan dalam 2 butir) belum dapat menjadi bagian yang repesentatif untuk terlibat di dalam menjelaskan variansi pengkuran terhadap keadaan terprovokasi. Karakteristik provokatif yang dimaksud adalah lemparan batu dari demonstran terhadap diri subjek, karakteristik provokatif seperti ini cenderung dapat menurunkan kekuatan butir untuk dapat mengkurnya. Penelitian ini masih sangat terbatas untuk dapat melibatkan ukuran responden dalam jumlah yang besar, sehingga konsekuensinya masih memerlukan kajian dengan melibatkan jumlah responden yang besar. Bentuk perilaku provokasi yang dituangkan dalam butir pengkuran mungkin belum ideal untuk dapat dikatakan sesuai dengan realitasnya, sehingga masih diperlukan beberapa bentuk perilaku provokasi yang nyata terjadi saat polisi mengamankan aksi unjuk rasa.

\section{Daftar Pustaka}

Aiken, L. . (1980). Content validity and reliability of single items or qustionare. Educational and Psychological Measurement., 40(4), 955-959.

Anderson, C. A., \& Bushman, B. J. (2002). Human Aggression. Anual Review Psychology, 53, 27-51. https://doi.org/10.1146/annurev.psych.53.100901.135231 
Aronson, E., Wilson, T. ., Akert, R. ., \& Sommers, S. . (2016). Social Psychology Ninth Edition. https://doi.org/10.1037/11571-001

Branch, A. (2015). Emotional Autonomy and Parental Stylesas a Predictor of Positive Identity Style. The 2015 International Academic Research Conference, (October), 22-24.

Bushman, B. J. (2002). Does Venting Anger Feed or Extinguish the Flame? Catharsis, Rumination, Distraction, Anger, and Aggressive Responding. Personality and Social Psychology Bulletin, 28(6), 724-731. https://doi.org/10.1215/00127094-2795217

Crotts, K., Sireci, S. G., \& Zenisky, A. (2012). Evaluating the content validity of multistageadaotive Tests. 13.

Dewall, C. N., Anderson, C. A., \& Bushman, B. J. (2011). The general aggression model: Theoretical extensions to violence. Psychology of Violence, 1(3), 245-258. https://doi.org/10.1037/a0023842

Hutahaean, E. S. H., Pertiwi, Y. W., Dayita Pohan, H., Perdini, T. A., \& Bastoro, R. (2021). Efek Tayangan Demonstrasi Sebagai Stimulus Untuk Pengaruhi Aktivitas Denyut Jantung Sebagai Representasi Reaksi Kemarahan. Jurnal Kajian IImiah, 21(2), 159-170. https://doi.org/10.31599/jki.v21i2.572

Junaidi, M., \& Marzuki, M. (2016). Konflik Komunal Nunu dan Tavanjuka di Kota Palu: Meniti Jalan Panjang Menuju Perdamaian. Etnohistori: Jurnal Ilmiah Kebudayaan Dan Kesejarahan, 3(2), 119-210.

Juujärvi, P., Kaartinen, J., Laitinen, T., Vanninen, E., \& Pulkkinen, L. (2006). Effects of physical provocations on heart rate reactivity and reactive aggression in children. Aggressive Behavior, 32(2), 99-109. https://doi.org/10.1002/ab.20129

Long, K., Felton, J. W., Lilienfeld, S. O., \& Lejuez, C. W. (2014). The role of emotion regulation in the relations between psychopathy factors and impulsive and premeditated aggression. Personality Disorders: Theory, Research, and Treatment, 5(4), 390-396. https://doi.org/10.1037/per0000085

Mauss, I. B., Cook, C. L., \& Gross, J. J. (2007). Automatic emotion regulation during anger provocation. Journal of Experimental Social Psychology, 43(5), 698-711. https://doi.org/10.1016/j.jesp.2006.07.003

Miles, S. R., Menefee, D. S., Wanner, J., Tharp, A. T., \& Kent, T. A. (2015). The Relationship Between Emotion Dysregulation and Impulsive Aggression in Veterans With Posttraumatic Stress Disorder Symptoms. Journal of Interpersonal Violance, 1(22), 1-22. https://doi.org/10.1177/0886260515570746

Pedersen, W. C., Denson, T. F., Goss, R. J., Vasquez, E. A., Kelley, N. J., \& Miller, N. (2011). The impact of rumination on aggressive thoughts, feelings, arousal, and behaviour. British Journal of Social Psychology, 50(2), 281-301. https://doi.org/10.1348/014466610X515696

Reio, T. G., \& Shuck, B. (2015). Exploratory Factor Analysis: Implications for Theory, Research, and Practice. Advances in Developing Human Resources, 17(1), 12-25. https://doi.org/10.1177/1523422314559804

Scott, L. N., Stepp, S. D., \& Pilkonis, P. A. (2014). Prospective associations between features of borderline personality disorder, emotion dysregulation, and aggression. Personality Disorders: Theory, Research, and Treatment, 5(3), 278-288. https://doi.org/10.1037/per0000070

Sireci, S. G. (1998). The construct of content validity. Social Indicators Research, 45(1-3), 83117. https://doi.org/10.1023/a:1006985528729

Sutatminingsih, R., \& Tuapattinaja, J. M. (2019). Efektivitas Komunikasi Interpersonal dan Perilaku Agresif Pada Anggota Satuan Dalmas Poldasu. Jurnal IImiah IImu Komunikasi Communique, 2(1), 10-17.

Thompson, R. A. (2011). Emotion and emotion regulation: Two sides of the developing coin. Emotion Review, 3(1), 53-61. https://doi.org/10.1177/1754073910380969

Wahlström, M. (2011). Taking Control or Losing Control? Activist Narratives of Provocation and Collective Violence. Social Movement Studies, 10(4), 367-385. https://doi.org/10.1080/14742837.2011.614107

Wang, Y., She, Y., Colarelli, S. M., Fang, Y., Meng, H., Chen, Q., ... Zhu, H. (2018). Exposure to nature counteracts aggression after depletion. Aggressive Behavior, 44(1), 89-97. https://doi.org/10.1002/ab.21727 